\title{
On Some Issues of Assessing the Efficiency of Renewable Energy Power Plants and the Share of Renewables in the World's Electricity Generation
}

\author{
Pavel Pavlovith Bezrukikh \\ Hydropower and Renewable Energy Sources Department, the National Research University “Moscow Power Engineering Institute”, \\ Russia
}

\begin{abstract}
The paper considers some issues related to the evaluation of power plants using renewable energy sources: energy efficiency, economic efficiency, the share of renewable energy in the world's electricity generation. At one time in the world there was a myth that more energy is expended on the construction of wind and photoelectric power stations, than they produce for the service life. Adherents of this myth are still found in Russia. In response to this myth, numerous studies have been carried out for the manufacturers of wind turbines and photovoltaic modules. It was proved that these power plants spent energy on them are produced within a period of less than a year and the energy consumed by them cannot be taken into account, since it is renewable. The author showed that power plants on organic fuel and existing nuclear plants using depleted fuel with a coefficient less than unity fundamentally cannot compensate for the energy used during their construction. In the world, the concept of the LEC (Levelized Energy Cost) produced by any power plant is widely used to estimate economic efficiency. However, the formula for determining it, in the author's opinion, contains an inaccuracy, which is proposed to be eliminated. At present, there are different opinions on the role of RES (Renewable Energy Sources) in the production of electricity. A summary indicator is the share of renewable energy in the world's electricity generation. The determination of the actual share of RES and the forecast of its growth is of significant importance for the development of the world economy. The author shows the differences in the estimates and suggests an approach for establishing agreed estimates.
\end{abstract}

Key words: Energy efficiency, EPBT (energy payback time), LEC, growth rate, weighted capacity factor, share of RES in electricity production.

\section{Introduction}

The paper offers a new look at the assessment of the EPBT (energy payback time), power plants on organic fuels. This indicator means the time period when the energy used to create them returns. It is shown that for fuel power stations and nuclear power plants, unlike wind, solar and hydraulic power stations, the generally accepted concept of the energy payback period is not applicable because in the process of work they consume fossil fuels. While solar, wind and hydraulic stations and stations use an inexhaustible (renewable) resource - the energy of the sun.

Corresponding author: Pavel Pavlovith Bezrukikh, professor, research fields: renewable energy sources and electricity.
The formula for determining the LCOE (levelized cost of electricity) production at power plants, or LCOE, in the author's opinion, contains an inaccuracy that significantly affects the final result.

It is shown that at present there are significant differences in the estimation of the share of RES in the production of electricity in the world.

To substantiate this statement, the author presents the results of calculations performed by the author, the weighted average capacity factor for installed capacity in wind, photovoltaic, bio and geothermal power plants and the production of electricity by these stations in the world, as well as the share of RES.

According to calculations, the share of RES in 2016 in the production of electricity was $10.3 \%$, and 
according to REN21, 2017-7.9\%. The greatest discrepancy was obtained by the share of the wind farm-288 TWh.

The approach methodology proposed by the author allows to establish an agreed estimate of the share of RES.

\section{Energy Efficiency}

As is known $[1,2]$, the EPBT is a generalized indicator of energy efficiency for wind, sun, water flows, tides and waves power plants. This is the ratio of the energy expended on the construction of the station $\left[\mathrm{E}_{\text {exp }}\right]$, including the extraction and transportation of raw materials, the production of materials, components and equipment, and then throughout the entire work cycle, including the decommissioning of the power plant to the average annual (over lifetime) electricity production $\left(\mathrm{E}_{\mathrm{py}}\right)$ minus the expense for own needs ( $\left.\mathrm{E}_{\text {oper }}\right)$. Ratio of the energy is expanded for the sake of construction.

$$
\mathrm{EPBT}=\mathrm{E}_{\exp } /\left(\mathrm{E}_{\mathrm{py}}-\mathrm{E}_{\mathrm{oper}}\right)
$$

or, if you neglect spending on your own needs

$$
\mathrm{EPBT}=\mathrm{E}_{\mathrm{exp}} / \mathrm{E}_{\mathrm{py}}
$$

Many works have shown in particular $[1,2]$ that for EPBT wind turbines it is less than one year, and for photovoltaic stations-from 0.7 to 2 years.

However, this approach to the evaluation of fuel power plants, as well as nuclear thermal neutrons, cannot be extended, because in the production process, they consume fuel, the reserves of which are depleted. For these power plants, the formula for determining the energy payback period will be:

$$
E P B T=\frac{E_{\text {exp }}}{E_{p y}}+\frac{F_{u s}}{E_{p y}} \cdot T_{\text {life }}
$$

where $F_{\text {us }}$ is the annual energy equivalent of resource used - coal, oil, gas, etc.

Since $\mathrm{F}_{\mathrm{us}} / \mathrm{E}_{\mathrm{py}}=1 / \mathrm{CFU}>1$, then EPBT $>\mathrm{T}_{\text {life, }}$, where CFU—coefficient of fuel using $\mathrm{T}_{\text {life }}$ - time life of plant.

For example, taking the fuel utilization factor for a condensation plant equal to $50 \%$, we find that the energy payback period is at least twice longer than the service life of the station. In other words, a thermal and nuclear power plant with thermal neutrons will never come up their EPBT.

Hence the inevitability of the gradual transition of world energy to use renewable energy sources. In this context, we do not consider power stations on biomass and geothermal energy. The problem is that, in general, these are renewable energy resources, and for specific power plants, the resource can be depleted.

\section{Economic Efficiency}

In the world, but, unfortunately, not in Russia, it is quite fair to determine the cost of produced energy for the entire lifetime [3]. There are three variants of the name of this indicator: LCOE (Levelized Cost of Energy), LCOE (Levelized Cost of Electricity), LEC (Levelized Energy Cost).

Formulas for determining LEC in different sources differ in some nuances, but the essence is the same. The most common formula is given below.

$$
L E C=\frac{\sum_{t=1}^{n} \frac{I_{t}+M_{t}+F_{t}}{(1+r)^{t}}}{\sum_{t=1}^{n} \frac{E_{t}}{(1+r)^{t}}}[\$ / \mathrm{MWh}]
$$

where:

$I_{\mathrm{t}}$-investment expenses in the year $t$,

$M_{\mathrm{t}}$-operating and maintenance expenses in the year $t$,

$F_{\mathrm{t}}$-fuel expenses in year $t$ (for solar, wind, hydraulic plants, it is zero),

$E_{\mathrm{t}}$-electricity generation in the year $t$,

$r$ - the discount rate,

$n$-the lifetime of the plant.

The correctness of the above formula raises doubts, despite the fact that it is generally accepted. The fact is that in the numerator the cost indicators $\left(I_{\mathrm{t}}, M_{\mathrm{t}}, F_{\mathrm{t}}\right)$ are divided into $(1+r)^{t}$ and this is quite true, since the subsequent costs must be brought to the beginning of construction. But in the denominator the generated 
electric energy $E_{\mathrm{t}}$, independent of the cost of capital, divided by $(1+r) t$, seems completely inexplicable. The energy produced by the power plant does not change its value depending on the time of its measurement.

At the risk of incurring the wrath of the mighty organizations involved in LEC calculations, I would nevertheless like to hear their arguments.

But the question arises: how to take into account in the cost of electricity the fact that burning fuel disappears irrevocably, and the sun, wind, watercourses-it is an eternal resource. Those circumstances should be reflected in the cost of electricity from fuel power stations, in addition to cost. And even if the society agreed to increase the electricity tariff, this would not be the answer to the question posed below. How do we take into account the exhaustion of fuel resources in the cost of electricity from thermal power plants? In other words: how to establish a correct comparison of power plants on depleted fuel and power plants on renewable energy sources?

\section{Estimation of the Share of RES in the Production of Electricity in the World}

It is well known that in the evaluation of the share of RES in the production of electricity in the present and future, there are different approaches to "interested" organizations. On the one hand, we have optimistic views of various associations for certain types of renewable energy. So associations on the study of wind and solar energy almost every year announce the records of input capacity.

On the other hand, we have very pessimistic assessments of a number of international energy organizations, oil and gas energy companies, although many of them successfully implement the construction and operation of power plants based on RES. However, they are extremely cautious in forecasting the share of RES. Let us consider the proposed estimation method based on data for 2016 .
The proposed approach to the assessment of the existing share of renewable energy in the production of electricity based on RES is as follows:

- a concerted assessment of electricity production in the world in the reporting year or recognition of the leading role in this matter of an organization in the world;

- determining in each country the installed capacity, the volume of electricity production based on RES and for each type of RES and forms of a weighted average capacity factor of installed capacity;

- determination of the weighted average capacity factor of the installed capacity for each type of renewable energy in the world as a whole, and electricity generation based on RES in general and separate types;

- determination of the share of RES and certain species in the global electricity production.

So, what are the results of implementing the above approaches?

For electricity production in the world, the author relies on BP data [4], according to which the production of electricity by all power plants in the world in 2016 was 24,816.4 TWh.

According to REN21 [5], the share of electricity production based on RES was: $4 \%$ on wind power plants or, if based on the above-mentioned total production volume, $992 \mathrm{TWh}$; in biomass power plants-2\% or $496 \mathrm{TWh}$, at photovoltaic stations $-1.5 \%$ or $372 \mathrm{TWh}$; on thermodynamic, tidal and geothermal REN $21-0.4 \%$ or $92 \mathrm{TWh}$, and total RES—only $7.9 \%$ or $1,959 \mathrm{TWh}$.

Let's consider what happens when implementing the methodology proposed above.

In Ref. [5], data are given on the average weighted capacity factor for the use of installed capacity by continents and regions (Africa, Asia, Central America and the Caribbean, Eurasia, Europe, Middle East, North America) and countries (China, India, Untied States) for power plants at base of the above-mentioned power plants. 
Table 1 Evaluation of RES share in electricity generation in the world.

\begin{tabular}{|c|c|c|c|c|c|c|c|}
\hline \multirow[b]{2}{*}{$\begin{array}{l}\text { Tape } \\
\text { of } \\
\text { power }\end{array}$} & \multirow{2}{*}{$\begin{array}{l}\text { Renewable } \\
\text { power capacity } \\
\text { (total) in } 2016 \text {, } \\
\text { GW }\end{array}$} & \multicolumn{2}{|c|}{ Estimation of REN21 } & \multicolumn{3}{|c|}{ Estimation of author } & \multirow[b]{2}{*}{$\begin{array}{l}\text { - Difference in } \\
\text { estimates } \\
\text { TWh }\end{array}$} \\
\hline & & $\begin{array}{l}\text { Electricity } \\
\text { production, } \\
\text { TWh }\end{array}$ & $\begin{array}{l}\text { Share of global } \\
\text { electricity production, } \\
\%\end{array}$ & $\mathrm{~K}_{\mathrm{hc}}$ & $\begin{array}{l}\text { Electricity } \\
\text { production, } \\
\text { TWh }\end{array}$ & $\begin{array}{l}\text { Share of global } \\
\text { electricity production, } \\
\%\end{array}$ & \\
\hline Wind & 487 & 992 & 4 & 0.3 & 1,280 & 5.15 & +288 \\
\hline $\begin{array}{l}\text { Solar } \\
\text { PV }\end{array}$ & 303 & 372 & 1.5 & 0.17 & 451 & 1.8 & +79 \\
\hline Biomass & 112 & 496 & 2 & 0.75 & 736 & 2.96 & +240 \\
\hline $\begin{array}{l}\text { Ocean, SCP, } \\
\text { Geothermal }\end{array}$ & $\begin{array}{l}\text { GeoES } \\
13.5\end{array}$ & 99 & 0.4 & 0.8 & $\begin{array}{l}\text { GeoES } \\
95\end{array}$ & 0.4 & -4 \\
\hline Total & - & 1,959 & 7.9 & - & 2,562 & 10.3 & \\
\hline
\end{tabular}

For the same continents, regions and countries, data on the installed capacity are given in Ref. [6].

On the basis of these data, the capacity factor of using the installed capacity $\left(K_{\mathrm{hc}}\right)$ in the world for certain types of RES was determined. With one exception in Ref. [6] for the United States on solar PV the weighted average capacity factor is equal to 0.19 , which, apparently, is a typo. The author, according to the data [7], where the power and the generation of electricity were indicated by the months of 2015 and 2016 at photovoltaic stations, determined the weighted average capacity factor of 0.327 , which was adopted to determine the total $K_{\mathrm{hc}}$ for the world's PV stations.

The following results were obtained for $K_{\mathrm{hc}}$ : wind farms -0.3 , photovoltaic stations -0.17 , stations on biomass -0.75 , geothermal stations -0.8 .

Calculation of annual electricity production $(E)$ was carried out according to the known formula.

$$
E=P \cdot T \cdot K_{\mathrm{hc}}
$$

where $P$ is the installed capacity, $T=8,760$ hours per year.

Installed capacity for certain types of renewable energy in 2016 was adopted in accordance with Ref. [5]:

$\mathrm{P}_{\mathrm{w}}=487 \mathrm{GW}, \mathrm{P}_{\mathrm{pv}}=303 \mathrm{GW}, \mathrm{P}_{\mathrm{Bio}}=112 \mathrm{GW}, \mathrm{P}_{\text {Geo }}$ $=13.5 \mathrm{GW}$.

The results of the calculations and their comparison with the REN21 data are placed in Table 1.

Electricity production in the world in 2016 was

\section{4,816.4 TWh [4].}

\section{Conclusion}

As we see, if we take as a basis the production of electricity in the world in the amount of $24,816.4$ TWh and the share of renewable energy in $7.9 \%$, according to REN21, the total production of electricity based on RES in the world will be 1,959 TWh.

And if, with the same in the estimates of the installed capacity by types of renewable energy, the average weighted capacity factor of the installed capacity usage is recognized as valid, then it turns out that in 2016 year 2,562 TWh were produced on the basis of renewable energy sources and the share of RES in total electricity production exceeded $10 \%$. And this is the milestone, which many analysts expected to achieve in 2020.

\section{References}

[1] Ghenai, C. 2012. "Life Cycle Analysis of Wind Turbine." In Sustainable Development: Energy, Engineering and Technologies-Manufacturing and Environment. Croatia: InTech Europe.

[2] Photovoltaic Power Systems Program. 2011. "Life Cycle Inventories and Life Cycle Assessment of Photovoltaic Systems." International Energy Agency Photovoltaic Power Systems Programme, Task 12, Report T-12-02.

[3] "Levelized Cost of Electricity Literature Review." Available at: http://www.appropedia.org/Levelised_Cost_of_Electricit y_Literature_Review.

[4] "BP Statistical Review of the World Energy June 2017." 
On Some Issues of Assessing the Efficiency of Renewable Energy Power Plants and the Share of Renewables in the World's Electricity Generation

[Full Report]. Available at: https://www.bp.com/content/dam/bp/en/corporate/pdf/ene rgy-economics/statistical-review-2017/bp-statistical-revie w-of-world-energy-2017-full-report.pdf.

[5] REN21. 2017. "Renewables 2017. Global Status Report." Available

at:

http://www.ren21.net/wp-content/uploads/2017/06/17-83 99_GSR_2017_Full_Report_0621_Opt.pdf.
[6] IRENA. 2017. "Renewable Capacity Statistics 2017." Available at: http://www.irena.org/publications/2017/Mar/RenewableCapacity-Statistics-2017.

[7] US Energy Information Administration. 2017. "Electric Power Monthly with Data for July 2017." Available at: http://large.stanford.edu/courses/2017/ph240/enriques1/d ocs/september2017.pdf. 